\title{
The Identification of Religious Behavior in the Archaeological Record
}

\author{
Kyle J Clark* and Craig T Palmer \\ Department of Anthropology, University of Missouri, USA
}

Submission: April 18, 2017; Published: June 14, 2017

*Corresponding author: Kyle J Clark, Department of Anthropology, University of Missouri, USA, Email: kjckbd@mail.missouri.edu

\section{Introduction}

Archaeologists have argued over how to identify religious behavior in the archaeological record for centuries. As Barrett [1] states in a recent review of the topic, "Because every stage of the archaeological process involves interpretation and theorization, archaeologists' theoretical stances and methodological choices shape the data they obtain." As Barrett [1] also points out, this process of interpretation starts with a definition of religion because "any discussion of the 'archaeology of religion' will be shaped by the author's (explicit or implicit) operational definition of 'religion' itself" (p.1).

In this brief article, we suggest one modification to typical definitions of religion that may aid the process of identifying religious behavior by setting the initial definition of religious behavior on more verifiable ground. The modification we propose is to follow a series of anthropologists who have argued that religious behavior is identified, not by beliefs, but by certain talk. Therefore, the goal of the archaeologist is not to identify material from which certain beliefs can be inferred, but to identify material from which this specific type of talk is inferred.

The advantage of such a modification starts with the simple fact that "statements about a people's religious beliefs must always be treated with the greatest caution, for we are then dealing with what neither European nor native can directly observe" (1965: 7). While many authors have pointed out problems with the "simplistic approach to religious belief" [24] see also Hahn 1973 that assumes a direct equation between people's statements and their beliefs, some have questioned whether beliefs can be identified "indirectly" by observing any possible pattern of other behaviors.

Perhaps the clearest statement of this problem has been made by Needham. In regard to the Penan of interior Borneo, Needham reports that, although he had been accustomed to saying that "they believed in a supreme god," he suddenly realized that he had no evidence at all to this effect. Not only that, but "I realized that I could not confidently describe their attitude to God, whether this was belief or anything else. In fact, as I had glumly to conclude, I just did not know what was their psychic attitude towards the person age in whom I had assumed they believed" (1972: 1).

Needham is also virtually alone in realizing the profound implications of this fact. The question then was whether the reports of other ethnographers were much better founded, and what evidence these really had that their subjects believed anything. Clearly, it was one thing to report the received ideas to which a people subscribed, but it was quite another matter to say what was their inner state (belief for instance) when they expressed or entertained such ideas. If, however, an ethnographer said that people believed something when he did not actually know what was going on inside them, then surely his account of them must, it occurred to me, be very defective in quite fundamental regards [5].

The task of the archaeologist trying to identify religion from material remains is challenging enough, without imposing the additional task of identifying beliefs from behavior (including talk), a task that may not be possible even when observing living people.

The shift from inferring belief to inferring certain talk is also directly relevant to a major topic in the archaeology of religion: the relationship of religion and ritual, and how to separate religious ritual from non-religious ritual. Rappaport argues that what distinguishes religious ritual from nonreligious ritual is not beliefs but rather supernatural claims, or what he calls "unverifiable propositions" [6]. For example, he states that "a religious ritual always includes an additional term, such as a statement about or to spirits" [6]. The realization that it is certain talk, not certain beliefs, that is identified as religious leads Rappaport to ask the question of whether or not participants in religious rituals actually believe the supernatural claims they make.

Although he has just finished stressing the fact that humans can lie (ibid.:261), he ignores this possibility and concludes: "It is thus plausible to assume a belief on the part of at least some of the participants in the existence of deceased ancestors; to assume otherwise would make nonsense of the proceedings"(ibid.: 262). 
In this statement Rappaport acknowledges that he cannot tell how many, or which, of the participants actually believe the supernatural claim, for he implies that the behavior of believers and nonbelievers is indistinguishable. Hence, the ritual will make just as much "sense" whether all, or some, or none of the participants believe in their claim.

There simply is no logical basis for his conclusion that it is safe to assume that "some" must believe because all of the activities identified as religious could be performed by a nonbeliever, and no one would be able to tell. Rappaport [7] appears to have also reach this conclusion in his 1999 book Ritual and Religion in the Making of Humanity where he writes "belief is an inward state, knowable subjectively if at all, and it would be entirely unwarranted either for us or for participants or witnesses to assume that participation in a ritual would necessarily indicate such a state." (120).

Obviously, the shift from belief to talk does not overcome many of the challenges involved in identifying religious behavior in the archaeological record. It does, however, at least make the starting point of ethnographic analogy explicit and verifiable. Because communicating acceptance of a supernatural claim is verifiable, the material culture associated with such talk in the ethnographic record is also verifiable. This provides a verifiable starting point to the archaeological study of religious behavior.

A common example of when belief shifts to talk occurs when archaeologists assert that the presence of food or objects in mortuary assemblages is an indication for belief in an afterlife. Fogelin [8] claims that identifying belief in an afterlife is the most important step in understanding the religion of past peoples. However, as Metcalf \& Huntington [9] point out, archaeologists "cannot excavate belief". Archaeologists cannot identify beliefs in burials just as ethnographers cannot identify beliefs in rituals. What are identifiable for ethnographers are the supernatural claims associated with such burials, and this is what may provide the most useful analogy for archaeologists to use in the past [10].

\section{References}

1. Barrett C (2016) Archaeology of Ancient Religions. In: Barton J (Ed.), Oxford Research Encyclopedia of Religion. Oxford Research of Religion, Oxford University Press, New York, USA.

2. Hilty DM (1988) Religious belief, participation and consequences: An exploratory and confirmatory analysis. Journal for the Scientific Study of Religion 27(2): 243-259.

3. Saler, Benson (1973) Clichés and the Study of Beliefs. Paper presented at the $72 \mathrm{~d}$ annual meeting of the American Anthropological Association, New Orleans.

4. Kirsch TG (2004) Restaging the Will to Believe: Religious Pluralism, Anti-Syncretism and the Problem of Belief. American Anthropologist 106(4): 699-709.

5. Needham R (1972) Belief, Language, and Experience. University of Chicago Press, Chicago.

6. Rappaport RA (1971) Ritual, sanctity, and cybernetics. American Anthropologist 73(1): 59-76.

7. Rappaport RA (1999) Ritual and Religion in the Making of Humanity. Cambridge University Press, UK.

8. Fogelin L (2007) Delegitimizing Religion: The Archaeology of Religion as. In: Whitley DS \& Gilpin KH (Eds.), Belief in the Past: Approaches to the Archaeology of Religion. Routledge, Taylor \& Francis, UK, pp. 129143.

9. Metcalf P, Richard H (1991) Celebrations of Death: The Anthropology of Mortuary Ritual. Cambridge University Press, UK.

10. Steadman LB, Palmer CT (2008) The Supernatural and Natural Selection. Boulder Paradigm Publishers.

\section{Your next submission with Juniper Publishers will reach you the below assets}

- Quality Editorial service

- Swift Peer Review

- Reprints availability

- E-prints Service

- Manuscript Podcast for convenient understanding

- Global attainment for your research

- Manuscript accessibility in different formats

( Pdf, E-pub, Full Text, Audio)

- Unceasing customer service

Track the below URL for one-step submission https://juniperpublishers.com/online-submission.php 